\title{
ENTRE BANDIDOS E REBELDES: O CANGAÇO SOB A PERSPECTIVA DA TEORIA DAS TÉCNICAS DE NEUTRALIZAÇÃO
}

\author{
BANDITS AND REBELS: BROKEN UNDER THE PERSPECTIVE OF \\ THE THEORY OF NEUTRALIZATION TECHNIQUES
}

\section{Alden Ferreira Lopes ${ }^{1}$}

ISSUE DOI: $10.21207 / 1983.4225 .361$

\section{RESUMO}

Este artigo aborda o cangaço sob a ótica criminológica, especificamente pela teoria das técnicas de neutralização, buscando através dela uma percepção que comporte e esclareça o eterno embate acerca do caráter e da causa desse fenômeno social. Para tanto, optou-se pela análise das teses mais elaboradas sobre o tema. Por um lado, a teoria do banditismo social, de Eric Hobsbawm, a qual compreende o cangaço dentro do conflito de classes em sociedades pré-capitalistas, concebendo o cangaceiro como um modelo primitivo de revolucionário. Em contraponto, adotaram-se os estudos de Frederico Pernambucano de Mello, dos quais surge a abalizada teoria do escudo ético, retratando o cangaceiro sem o viés ideológico e rebelde visto na anterior. Assim, sem fugir dos embaraços decorrentes desse debate maniqueísta, intentou-se inserir o cangaço e suas interpretações contrapostas no olhar vasto e multifacetado das teorias sociológicas da criminologia, pretendendo com isso uma convergência entre estes dois

\footnotetext{
${ }^{1}$ Bacharel em Direito pela Universidade do Estado da Bahia (2013), pós-graduado lato sensu em Criminologia, Política Criminal e Segurança Pública pela Uniderp/Anhanguera (2016). Atuou como advogado entre 2013 a 2014. Exerceu o cargo de Técnico Judiciário do Tribunal de Justiça do Estado de Pernambuco. Atualmente, é Delegado de Polícia Civil do Estado da Bahia. Tem experiência na área de Direito, com ênfase em Direito Penal e Processual Penal.
} 
enfoques, intermediada pelas teorias de base marxista - com as devidas alterações, obviamente, haja vista o paradigma socioeconômico sob o qual se ergueu a criminologia radical, qual seja, a dicotomia capitalista "burguês-proletário", a qual não existia na época do cangaço - e pela teoria das técnicas de neutralização, de Sykes e Matza.

Palavras-chave: Banditismo social. Cangaço. Pré-capitalismo. Messianismo. Criminologia crítica. Maniqueísmo. Anomia.

\section{ABSTRACT}

This article approaches the cangaço from the criminological point of view, specifically by the theory of neutralization techniques, seeking through it a perception that bears and clarifies the eternal conflict about the character and cause of this social phenomenon. For that, we opted for the analysis of the most elaborated theses on the subject. On the one hand, the theory of social banditry, by Eric Hobsbawm, which comprises the cangaço within the class conflict in pre-capitalist societies, conceiving the cangaceiro as a primitive model of revolutionary. In opposition, the studies of Frederico Pernambucano de Mello were adopted, from which the established theory of the ethical shield arises, portraying the cangaceiro without the ideological and rebellious bias seen in the previous one. Thus, while avoiding the embarrassments arising from this Manichean debate, the attempt was made to insert the cangaço and its opposing interpretations in the vast and multifaceted view of the sociological theories of criminology, thereby seeking a convergence between these two approaches, intermediated by Marxist-based theories The obvious alterations, obviously, are the socioeconomic paradigm under which radical criminology arose, that is, the "bourgeois-proletarian" capitalist dichotomy, which did not exist at the time of the cangaço - and by the theory of neutralization techniques, of Sykes and Matza.

Keywords: Social banditry. Cangaço. Pre-capitalism. Messianism. Criminology Critical. Manichaeism. Anomia. 


\section{INTRODUÇÃO}

Nunca houve uma interpretação consensual do cangaço, seja na visão popular ou dos especialistas no assunto. Sobre esse fenômeno social sempre pairou uma percepção maniqueísta, para a qual, ou o cangaceiro era o herói vingador dos pobres do campo, ou, simplesmente, um bandido comum, motivado apenas por interesses individualistas - mais um a atuar na opressão do camponês.

De visões dualistas e simplificadoras como estas, a criminologia possui farto conhecimento, seja para legitimá-las - teorias etiológicas ou combatê-las - teorias críticas. Por essa razão, a ciência criminológica aparentou ser um campo fértil para a submersão do conflitivo tema cangaço, a fim de se buscar, com sua análise, não só uma perspectiva mais adequada e conclusiva sobre esse assunto, mas, sobretudo, a própria razão de tamanha divergência.

Na sociologia e historiografia, já se coletou farto material sobre o tema, permitindo-se, inclusive, a elaboração de teorias sobre esse fenômeno social. Nesse sentido, ganhou destaque a teoria do banditismo social desenvolvida pelo historiador Eric Hobsbawm. De igual modo, a crítica a esta obra também merece destaque, sendo contemplada neste trabalho pela adoção da teoria do escudo ético, de Frederico Pernambucano de Mello. Na seara criminológica, contudo, tal fenômeno resta ainda intacto, clamando por uma iniciativa que, no mínimo, vislumbre sua compatibilidade dentro de alguma de suas teorias.

Sem que se afaste o cabimento de outras correntes criminológicas, afinal o vasto número destas impossibilitaria a abordagem de todas no reduzido espaço deste artigo, optou-se pela análise do cangaço por meio da teoria das técnicas de neutralização, de Sykes e Matza, reforçada pela concepção dialética marxista.

Desse modo, objetiva-se esclarecer o contexto de violência, admiração, terror e rebeldia que caracterizou o cangaço, fora da insuficiente delimitação entre bandidos ou heróis. Longe disso, alheio a qualquer extremismo ou simplificação, intenta-se compreender tal fenômeno justamente sob seu duplo aspecto, ainda que para isso tenha-se que realizar alguns reparos nas teorias empregadas. 


\section{CANGAÇO: CONTEXTO HISTÓRICO, SOCIAL, POLÍTICO E ECONÔMICO}

É inegável que, desde o século XVII, em pleno litoral nordestino, há relatos históricos das ações de grupos de bandoleiros causando, já naquela época, medo e insegurança na população. Contudo, é só no século XIX, com seu florescimento no sertão, que tal forma de banditismo ganha relevo e singularidade, nascendo, também nesse período, a denominação que carregaria até os dias atuais, qual seja, cangaço ${ }^{2}$. Justamente a partir de meados desse século, há o surgimento dos maiores expoentes do cangaceirismo, dentre eles: Sinhô Pereira, Antônio Silvino, Lampião e Corisco.

Na certa, não se trata de mera coincidência que, num mesmo local e em igual época, tenha florescido um fenômeno tão peculiar e de propagação tão semelhante. Houve, obviamente, fatores e condicionantes exclusivos que semearam sua materialização.

De início, o isolamento geográfico e a aridez do sertão já apontam para um terreno de agruras, que exige do seu desbravador bravura e coragem diferenciadas, ao ponto que o "habitat" e o habitante duelam entre si pela liberdade - ou a seca expulsa o sertanejo, o que é mais comum, ou o sertanejo subjuga a caatinga. Desde esse ponto, já se anuncia o perfil daqueles que povoavam esse ambiente, homens adaptados às constantes secas, à falta de contato com o avanço externo, ao distanciamento do poder público, à ausência da justiça, em suma, um indivíduo moldado física e socialmente para um universo rústico e adverso.

Dentro dessas condições, ajustou-se toda uma cultura peculiar, marcada por uma religiosidade de fundo místico ${ }^{3}$ e um código ético ${ }^{4}$ dig-

\footnotetext{
2 “... com o deslocamento do foco central do banditismo para o sertão, onde aliás ele viria a receber o batismo de 'cangaço', não desapareceria o banditismo litorâneo... a partir da primeira metade do século XIX, as evidências históricas demonstram que esta forma de criminalidade passa a se desenvolver no sertão em ritmo idêntico ao da sua decadência no litoral" MELLO, Frederico Pernambucano de. Guerreiros do Sol: Violência e banditismo no Nordeste do Brasil. São Paulo: A Girafa, 2004, p. 95.

3 “... em torno de um beato ou conselheiro, para implorar dádivas aos céus e remir os pecados, que seriam as causas de sua desgraça” FACÓ, Rui. Cangaceiros e fanáticos: gênese e lutas. Rio de Janeiro: UFRJ, 2009, p. 47.

4 O que Frederico Pernambucano denota como "paralelismo normativo", relatando que "Chega a ser quase impossível, por exemplo, explicar ao homem do sertão do Nordeste as
} 
no dos romances feudais. Nesse ponto, a moral sertaneja era familiarizada com a violência e o conservadorismo, conferindo à honra um valor que nem mesmo o bem jurídico vida detinha. Uma afronta à dignidade de alguém impunha à vítima um desagravo à altura ${ }^{5}$, o qual, se não fosse levado a efeito, representaria uma demonstração de fraqueza do ofendido, abrindo-se assim, por meio do controle social informal ${ }^{6}$, o caminho para sua segregação social.

Com fulcro nesse universo de valores rústicos, a vingança surgirá como a principal justificativa para o alistamento nas trincheiras do cangaço. Seja isso verdade, ou mera desculpa para ocultar razões menos nobres, certo é que tal alegação era moralmente reconhecida pelos sertanejos, retirando do cangaceiro a reprovação social que lhe adviria, por exemplo, se se tratasse de um mero ladrão de galinhas.

Quanto ao aspecto econômico, predominava na região a cultura agropecuária, desenvolvida na extensão de imensos latifúndios, sob a titularidade de poucos privilegiados. Estes se valiam da mão-de-obra semi-servil do homem do campo, assemelhando-se em muito à relação de produção do período feudal, pois em ambas o monopólio da terra servia para oprimir e explorar o pobre camponês sem qualquer intervenção de um poder superior.

Como já era de se esperar, nesse ambiente marcado pelo distanciamento do Estado, tal poderio econômico dos latifundiários era ainda acompanhado do seu respectivo poder político. Assim, o coronelismo tornara-se característica indissociável da civilização sertaneja, tal como o cinza é da caatinga.

razões por que a lei penal do país - informada por valores urbanos e litorâneos que não são os seus - atribui penas mais graves à criminalidade de sangue, em paralelo com as que comina punitivamente para os crimes contra o patrimônio...”. MELLO, Frederico Pernambucano de. Guerreiros do Sol: Violência e banditismo no Nordeste do Brasil. São Paulo: A Girafa, 2004, p. 127.

5 “... a violência empregada na satisfação de um ideal de vingança, em que o gesto de desafronta é visto como um direito e até mesmo um dever do afrontado, de sua família e de amigos mais chegados" MELLO, Frederico Pernambucano de. Guerreiros do Sol: Violência e banditismo no Nordeste do Brasil. São Paulo: A Girafa, 2004, p. 63.

${ }^{6}$ Segundo Lola Aniyar de Castro Criminologia da libertação. Rio de Janeiro: Revan, 2005, p. 153, "é uma intensa e multifacética maneira de educar os indivíduos, e desse modo as massas, do nascimento até a morte", efetuado por instituições não oficiais como igreja, família, escola ou sindicato. 
Nesse cenário, o poder político-econômico dos coronéis era absoluto - nos termos atuais, despontava como se englobasse sozinho o poder jurisdicional, executivo e legislativo - regulando, ao seu alvedrio, a vida e a liberdade do camponês, encontrando limites somente na autoridade de outros coronéis - causa frequente de conflitos armados, nos quais o cangaço teve imensa participação. Os governos estaduais e federal, por sua vez, fomentavam o mandonismo local, valendo-se dele para controlar regiões às quais não detinham acesso direto e imediato, assim como para fins eleitoreiros, afinal desses confins provinha parcela dos seus votos, alimentados pela ardilosa prática do voto de cabresto.

Para que não reste dúvida acerca da relevância dos fatores supracitados à propagação do cangaço, basta notar que a sua derrocada coincidiu com a supressão ou redução de tais elementos. Com a chegada de estradas, vias férreas e meios de comunicação que interligavam os sertões aos grandes centros, aumento da intervenção federal por força da política centralizadora e repressiva de Getúlio Vargas - consequentemente seguida da redução dos mandonismos locais -, além dos acordos políticos estaduais para uma atuação policial conjunta, o cangaço finda seu ciclo. Assim, o contato com os avanços e contradições do meio externo tirou o sertão da sua estagnação política, social e econômica, confrontando suas relações de poder, cultura e seu modo de produção com uma nova realidade - infértil para essa forma de banditismo.

\section{VILÕES OU HERÓIS: LAMPIÃO, UM HOMEM, DUAS HISTÓRIAS}

O cangaço, assim como a maioria dos fenômenos sociais, não foi um todo homogêneo, no qual os seus personagens ingressaram e o representaram de forma idêntica. Seus maiores expoentes (Lampião, Antônio Silvino e Sinhô Pereira) deram vazão a distintas categorias, elaboradas, sobretudo, com base nas razões que os levaram a adentrar e permanecer no cangaço ${ }^{7}$.

\footnotetext{
${ }^{7}$ MELLO, Frederico P. de. Guerreiros do Sol: Violência e banditismo no Nordeste do Brasil. São Paulo: A Girafa, 2004, p. 140, classifica-o em três formas básicas: cangaço meio de vida; cangaço de vingança e cangaço refúgio. Na sua concepção, Lampião se enquadrava na primeira categoria.
} 
Ocorre, contudo, que tais distinções não descaracterizam o estereótipo comum do cangaceiro, e sim assinalam, antes de tudo, peculiaridades que reforçam a preexistência de um só alicerce. Ademais, como a finalidade e o curto espaço deste artigo demandam objetividade no trato do tema, optou-se pela adoção de um cangaceiro em especial, como paradigma para a abordagem criminológica. A escolha recai justamente em seu maior expoente, Virgulino Ferreira, o "Lampião", seja por sua relevância intrínseca para a popularização do fenômeno, seja pela maior gama de estudos que sobre ele recai - permitindo assim uma análise mais robusta por meio da criminologia.

\subsection{BANDITISMO POR UMA QUESTÃO DE CLASSE}

Ao se falar em banditismo, paira no senso comum a imagem do fora da lei em confronto com toda a sociedade, infrator de regras legais e morais, sujeito desprovido de um propósito superior, que na sanha de satisfazer apenas seus próprios interesses e/ou necessidades, age em detrimento até mesmo dos seus pares. Via de regra, não se faz, portanto, qualquer distinção entre as diversas formas como esse fenômeno pode se manifestar.

Ocorre, contudo, que uma modalidade bastante específica de banditismo - porém de existência comum em diversas regiões do globo chamou a atenção dos historiadores e sociólogos. Denominado pioneiramente, por Eric Hobsbawm, de banditismo social, esse fenômeno social de abrangência universal reúne pressupostos e características bastante peculiares, capazes, inclusive, de permitir sua diferenciação do banditismo convencional ${ }^{8}$.

Na distinção proposta pela teoria do banditismo social, o bandido comum caracteriza-se por não agregar à sua atuação o comprometi-

\footnotetext{
${ }^{8}$ Não se quer dizer aqui que o banditismo comum, aquele com que diariamente nos deparamos, enquadra-se como uma espécie uniforme de manifestação delitiva, na qual os mais diferentes desvios nele inseridos possam ser observados como um fenômeno singular e homogêneo. Ao revés, sabe-se que, a depender da teoria criminológica empregada, pode haver distintas classificações e explicações para um fenômeno delitivo, ou, ainda, pode nem mesmo buscar-se explicação causal para ele, priorizando-se, inversamente, o controle social responsável pela criação desse rótulo estigmatizante, tal como a criminologia crítica faz.
} 
mento com os valores e interesses da comunidade em que se insere; importa-lhe, somente, a satisfação das suas aspirações individuais, sem que nelas resida qualquer consciência de classe. Nos dizeres de Eric Hobsbawm, o submundo comum do crime "é uma antissociedade, que existe pela inversão dos valores do mundo 'decente' - é um mundo, segundo sua própria definição, 'transviado' -, mas possui com este uma relação parasitária". 9

Isto é, o banditismo comum ostenta uma postura contrária tanto aos interesses das classes dominantes quanto ao dos dominados, pois, conforme relatado, comporta-se como um parasita, imbuído apenas da sua própria manutenção, ainda que em detrimento de toda a sociedade ${ }^{10} . \mathrm{Nu}$ ma concepção marxista, o lumpemproletariado, certamente, estaria incluído nessa categoria ${ }^{11}$.

O bandido social, por sua vez, guarda consigo as mesmas aflições e angústias suportadas pelos da sua origem e, por conseguinte, detém os mesmos ideais. Age, portanto, como o pequeno camponês agiria, se tivesse a oportunidade de inverter - ainda que por um minuto e nem que para isso lhe custasse a própria vida - a relação de submissão social, política e econômica sob a qual esteve debelado por toda sua vida. Em suma, "são esses os homens que alardeiam seu direito de serem respeitados por todos...". 12

Por essa razão, são vistos como criminosos pelo Estado e pelos detentores do poder. Já para parcela considerável de seus companheiros camponeses, eram considerados até mesmo heróis, vingadores das injustiças a que são submetidos cotidianamente, o que resultava no intenso apoio que a população lhes dava - cite-se, como exemplo, a ajuda dos coiteiros aos cangaceiros, a qual foi essencial para a longa sobrevivência destes.

\footnotetext{
${ }^{9}$ HOBSBAWM, Eric J. Bandidos. 4. ed. São Paulo: Paz e Terra, 2010. p. 129.

10 "Os ladrões profissionais e os pilhadores veem os camponeses como sua presa, e têm consciência da sua hostilidade. Por sua parte, as vítimas veem os atacantes como criminosos, segundo seus próprios termos, e não apenas porque assim diz a lei oficial". HOBSBAWM, Eric J. Bandidos. 4. ed. São Paulo: Paz e Terra, 2010, p. 36.

11 "Abstraindo vagabundos, delinquentes e prostitutas, em suma, o lumpemproletariado propriamente dito...” (grifou-se) MARX, Karl. O capital: crítica da economia política. Livro I: o processo de produção do capital. São Paulo: Nova cultural, 1996, p. 273.

${ }^{12}$ HOBSBAWM, Eric J. Bandidos. 4. ed. São Paulo: Paz e Terra, 2010. p. 59.
} 
Assim, nasce a via interpretativa do cangaço que maior ressonância teve entre os estudiosos de esquerda. Sob a perspectiva do banditismo social, vislumbrou-se no cangaceiro a figura de vingador dos oprimidos, representante inconsciente da revolta camponesa. Ainda que, para Hobsbawm, Lampião não se enquadrasse no perfil de um Robin Hood, isso não lhe retirava o título de bandido social. A crueldade e o terror, de fato, representavam seu modo de agir, contudo, esse se dava num contexto e por uma causa justificáveis. ${ }^{13}$

A violência e a brutalidade eram indissociáveis da vingança a que foram encarregados de concretizar, em nome dos cadáveres mudos que jaziam sobre seus ombros. ${ }^{14}$ Ademais, a vingança, àquela época, não tinha a conotação depreciativa de hoje, ao revés, era o termo mais utilizado para absolver os bandoleiros dos seus atos. A título de ilustração, citese o esclarecimento feito por Hobsbawm:

São heróis, não apesar do medo e horror que inspiram suas ações, mas, de certa forma, por causa delas. São menos desagravadores de ofensas do que vingadores e executores de poder; não são vistos como agentes de justiça - mas a vingança e a retaliação são inseparáveis de justiça em sociedades em que sangue se paga com sangue -, e sim como homens que provam que até mesmo os fracos podem ser terríveis. ${ }^{15}$

Eram, assim, autênticos representantes de uma classe sem meios e instrumentos legítimos de se furtar da opressão dos potentados rurais. Reagiam à estrutura que os explorava do mesmo modo que esta os tratava com brutalidade e sem piedade. Afinal, os frequentes abusos cometidos pelas volantes ${ }^{16}$ em muito se assemelham à concepção de genocídio em-

\footnotetext{
${ }^{13}$ HOBSBAWM, Eric J. Bandidos. 4. ed. São Paulo: Paz e Terra, 2010. p. 85.

${ }^{14}$ ZAFFARONI, Eugenio Raúl. A palavra dos mortos: conferências de criminologia cautelar. São Paulo: Saraiva, 2012. p. 39.

${ }^{15}$ HOBSBAWM, Eric J. Bandidos. 4. ed. São Paulo: Paz e Terra, 2010. p. 85.

16 “É sabido que as tropas da polícia agiam muitas vezes contra as populações rurais com maior ferocidade do que os cangaceiros e as intimidavam ainda mais do que aqueles. $\mathrm{E}$ não por acaso. A polícia estava convencida de que cada um daqueles míseros, sem terra e até mesmo sem trabalho, era um cangaceiro em potencial". FACÓ, Rui. Cangaceiros e fanáticos: gênese e lutas. Rio de Janeiro: UFRJ, 2009, p. 205).
} 
pregada por Zaffaroni, na sua elaboração da criminologia cautelar. De igual modo, a violência física, moral e psicológica praticada pelos coronéis, com a chancela das autoridades públicas, era mais um elemento do cotidiano sertanejo a influir na sua reação. ${ }^{17}$

Nesse ponto, questiona-se porque a barbárie e as infrações de uns mereceram atenção e reprovação pelo controle social formal, enquanto que as de outros restaram intocadas e, sobretudo, fomentadas. Resta claro que, como sempre, a criminalização secundária se voltava somente às classes oprimidas, selecionando, para submeter-se ao sistema penal, apenas quem julgava prejudicial à manutenção do status quo. Em contrapartida, a cifra negra da criminalidade dos coronéis e das volantes nem mesmo requeria um álibi, pois já justificada e legitimada de antemão pelo próprio poder público, como consequência inexorável do processo eliminatório de um inimigo ${ }^{18}$ social.

Por tais razões, nesse duelo de classes, no qual o débil trabalhador rural lutava sozinho contra os potentados rurais e o poder público, deve-se compreender que "a vítima só dispõe de seus próprios recursos, e entre estes a violência e a crueldade são os de eficiência mais visível". ${ }^{19}$ E, talvez por isso, Rui Facó, vislumbrando na atitude dos cangaceiros um autêntico viés revolucionário, tenha afirmado que "não se tratava de crimes individuais - não era, portanto, um crime, mas um problema social a enfrentar". 20

\subsection{BANDITISMO POR PURA MALDADE}

Todavia, em contraste com a visão idealista acima relatada, outros pesquisadores do assunto apontam ser totalmente surreal atribuir aos

17 ZAFFARONI, Eugenio Raúl. A palavra dos mortos: conferências de criminologia cautelar. São Paulo: Saraiva, 2012. p. 78.

18 "A essência do tratamento diferenciado que se atribui ao inimigo consiste em que o direito nega-lhe sua condição de pessoa. Ele só é considerado sob o aspecto de ente perigoso ou daninho". (ZAFFARONI, Eugenio Raúl. A palavra dos mortos: conferências de criminologia cautelar. São Paulo: Saraiva, 2012, p. 18).

${ }^{19}$ HOBSBAWM, Eric J. Bandidos. 4. ed. São Paulo: Paz e Terra, 2010. p. 92.

${ }^{20}$ FACÓ, Rui. Cangaceiros e fanáticos: gênese e lutas. Rio de Janeiro: UFRJ, 2009. p. 55. 
cangaceiros tal caráter revolucionário. Sobretudo pela ausência de qualquer ideologia na atuação desses grupos.

Ainda que tenha se autoproclamado governador do sertão, Lampião não propunha, a fim de justificar e legitimar sua insurgência à ordem posta, qualquer programa ou ideologia política para suplantar a macroestrutura vigente. Ele apenas retribuía toda a opressão e terror que, como todo sertanejo, havia sofrido dos detentores do poder, sem que com isso intentasse uma mudança revolucionária da estrutura social. Atuava, assim, não na raiz dos problemas - bradando pela formulação de uma nova forma de governo -, e sim na busca por retaliação aos efeitos inevitáveis de uma ordem desigual e injusta por excelência.

Reforçando a ausência de um programa político na ação dos cangaceiros, Frederico Pernambucano de Mello afirma:

Em nossos estudos sobre o cangaço profissional, quanto mais procuramos enxergar em seus representantes o sentido geral do protesto e, correspondentemente, a sua outra face, a da reforma, mais nos defrontamos com um sentido individualista de ascensão social, ascensão que, dentro do quadro todo próprio da sociedade sertaneja, tinha sem dúvida no cangaço uma de suas vias largas, pouco importando a ausência da chancela oficial do poder público, à base dos valores urbanos por estes desfraldados. $^{21}$

Não se causa surpresa, portanto, o fato de Lampião deter fortes relações com muitos coronéis, pois era mais seu cúmplice do que adversário. Conforme essa tese, o cangaceiro pactuava justamente com os tradicionais algozes do servo sertanejo, enquanto, contraditoriamente, ostentava a áurea de seu porta-voz.

Para os críticos da tese do "Lampião protorrevolucionário", nele havia, realmente, irresignação por sua condição e pelo seu passado de perseguição e tragédias familiares, porém esses não eram o único combustível para a sua insubmissão armada, ainda que fosse usual entre os cangaceiros alegar a vingança pessoal como motivação para os seus atos.

${ }^{21}$ MELLO, Frederico Pernambucano de. Guerreiros do Sol: Violência e banditismo no Nordeste do Brasil. São Paulo: A Girafa, 2004. p. 383. 
Justamente a vingança - que, como já se disse, no universo de valores sertanejo, era mais que um direito, um autêntico dever cívico seria repetidamente alegada. E para honrá-la, alguns homens não mediam esforços, largavam suas vidas comuns - difíceis e sofridas, porém comuns - e imergiam no mundo perigoso e bárbaro do cangaço, tudo por um imperativo moral. Tal atitude angariava grande respeito e a admiração dos seus pares, o que conferia tolerância e apoio aos que abraçavam essa causa nobre.

Firme na constatação do grande apelo a esse argumento pelos cangaceiros, como tentativa de imunizar as atrocidades cometidas, Frederico Pernambucano de Mello elaborou a teoria do escudo ético. Esta apregoa que a necessidade de justificar-se aos olhos dos demais e de si próprio conduziu o cangaceiro a abraçar o desagravo como explicação para as suas atitudes. Isto é, valendo-se de um argumento de forte valor moral no universo sertanejo, angariou para si o conforto psicológico e o apoio popular necessário para sua jornada fora da lei.

Segundo essa linha de raciocínio, Lampião gostava da vida que levava e dos fartos frutos que lhe rendia. Poder, glória, dinheiro e fama haviam se imiscuído no seu modo de vida, tornando o intuito vingativo do início de sua carreira um mero verniz para ocultar sua contraditória satisfação. Isto é, o cangaço era uma via atrativa para o sertanejo, ainda que fosse perigosa, ostentava o brilho de uma "ocupação aventureira, um ofício epicamente movimentado, um meio de vida, ou até mesmo um amadorismo divertido de jovens socialmente bem situados, carentes de afirmação". ${ }^{22}$

A fim de confirmar sua tese, o autor levanta um fato inquestionável: nos vinte anos de carreira subversiva do Rei do cangaço, nos quais já chegou a controlar verdadeiros exércitos ${ }^{23}$, nunca ele tentou seriamente findar a vida do seu principal algoz, José Saturnino, o responsável pelo infortúnio de sua família e principal causa para sua entrada no bandoleirismo. Se quisesse, disso não há dúvida, o teria feito.

\footnotetext{
${ }^{22}$ MELLO, Frederico Pernambucano de. Guerreiros do Sol: Violência e banditismo no Nordeste do Brasil. São Paulo: A Girafa, 2004. p. 117.

${ }^{23}$ No seu auge, 1926, cita-se que o bando já chegou a 150 homens. Ibidem, p. 97.
} 


\section{NEM BANDIDO, NEM HERÓI: SIMPLESMENTE HUMANO}

A forma simplista e primária de conceber o mundo como que dividido em dois lados, entre o bem e o mal, ainda é muito atual. Na criminologia, esse pensamento ganhou ares de cientificidade com o positivismo de Lombroso, Ferri e Garófalo, arrastando-se até hoje com os novos avanços científicos - o neolombrosianismo tem ganhado força com as recentes descobertas no campo da genética ${ }^{24}$. Para o senso comum, sobretudo, tal concepção maniqueísta mantém-se inabalável há séculos, afinal, antes mesmo de o positivismo legitimá-la, a religião já cumpria esse papel dignamente, sobretudo o cristianismo, como ainda o cumpre.

Desse modo, não impressiona que na análise de um fenômeno social, tal como o cangaço, procure-se direcionar sua interpretação à captação de uma intrínseca bondade, ou maldade, no perfil dos seus representantes - conforme se viu nos tópicos anteriores. Fatalmente, essa pretensão totalitária de aniquilamento da diversidade, pela simplificação da incontornável complexidade humana, limita o olhar do pesquisador, pois retira do seu objeto a própria essência que o distingue dos outros seres, qual seja, a sua subjetividade.

Ciente desse risco, optou-se neste artigo pela não adoção de uma só perspectiva, fugindo-se da concepção de Lampião como o Robin Hood do nordeste, ou, por sua vez, como o "homem delinquente" 25 do positivismo, portador de uma patológica maldade. Vê-se, sim, que ambos os argumentos adotados para descrever o perfil do cangaceiro podem ser muito bem o reflexo de uma só personalidade humana e, nesse aspecto, observou-se que a criminologia dispunha de vertentes teóricas que se conformariam a esse ponto de vista, tal como a teoria das técnicas de neutralização, capitaneada por Gresham Sykes e David Matza.

\footnotetext{
${ }^{24}$ As pesquisas científicas sobre o genoma humano têm alardeado um retrocesso à busca de causas biológicas para a delinquência. A título de ilustração, cite-se artigo sobre o tema. Disponível em: <http://sisnet.aduaneiras.com.br/lex/doutrinas/arquivos/2 70407.pdf>. Acesso em: 22 ago 2014.

${ }^{25}$ Nesse ponto, a teoria lombrosiana só serviu para absolver Lampião. "Examinado o seu crânio pela medicina especializada do país, não houve como fugir do laudo desconcertante: era um dolicocéfalo perfeito". MELLO, Frederico Pernambucano de. Guerreiros do
} Sol: Violência e banditismo no Nordeste do Brasil. São Paulo: A Girafa, 2004, p. 329. 
Em crítica feita à teoria das subculturas delinquentes ${ }^{26}$, Sykes e Matza aventaram a hipótese de que a violação à lei não representaria necessariamente uma rejeição aos valores dominantes, isto é, não significava a adoção de valores e normas de uma subcultura divergente. Ao revés, viram que os delinquentes juvenis - pois estes foram seu objeto inicial de estudo - também adotavam os valores convencionais, contudo, fugiam do dever de respeitá-los através de artifícios psicológicos que justificariam seus desvios.

Em síntese, o delinquente também compartilha dos princípios reitores da sua sociedade, só que, a depender de determinadas circunstâncias, compreende ser possível excepcioná-los - tal como a inexigibilidade de conduta diversa exclui, só que por expressa previsão legal, a culpabilidade. Em coerência com suas finalidades, Sykes e Matza denominaram tais "anestésicos psicológicos" do desvio como técnicas de neutralização e, a partir da reunião de todas elas, propuseram sua classificação em cinco categorias, quais sejam: negação da própria responsabilidade; negação de ilicitude; negação da vítima; condenação dos condenadores e apelo a lealdades superiores.

A primeira delas refere-se à atribuição da conduta ilícita a fatores alheios ao controle do agente, conforme exemplificação de Zaffaroni: "foram as circunstâncias; foi minha família; a sociedade me fez assim". 27 Negar a ilicitude significa não enxergar real violação ao bem jurídico protegido pela norma, "o delinquente interpreta as suas ações como somente proibidas, mas não imorais e danosas" 28 em virtude da insignificância do dano causado. A negação da vítima retira do sujeito passivo esta condição, pois, por algum aspecto particular, merecia sofrer a infra-

\footnotetext{
26 "Creemos que dichas técnicas constituyen un componente esencial de las "definiciones favorables para el incumplimiento de la ley" de Sutherland. Es a través del aprendizaje de estas técnicas que un joven se convierte en un delincuente juvenil, y no a través del aprendizaje de imperativos morales, valores o actitudes en total contradicción con aquellos de la sociedad dominante. Al analizar estas técnicas, nos pareció conveniente dividirlas en cinco grandes tipos". SYKES, Gresham M'Cready; MATZA, David. Técnicas de Neutralización: una teoría de la delincuencia. Salvador: Caderno CRH, 2008, p. 04. Disponível em: http://www.scielo.br/scielo.php?script=sci_arttext\&pid=S0103-4979200800010 0012. Acesso em: 21 de agosto de 2014.

27 ZAFFARONI, Eugenio Raúl. A palavra dos mortos: conferências de criminologia cautelar. São Paulo: Saraiva, 2012. p. 163.

${ }^{28}$ BARATTA, Alessandro. Criminologia crítica e crítica do direito penal: Introdução à sociologia do direito penal. 6. Ed. Rio de Janeiro: Revan, 2011. p. 78.
} 
ção, vista como punição (p. ex.: "gay tem mesmo que apanhar"; "mulher que trai merece morrer"). A condenação dos condenadores se vale da hipocrisia de certos detentores do controle social formal ou informal, que não cumprem as normas, mas exigem dos demais o seu respeito (p. ex.: o policial corrupto; o professor incompetente que exige excelência do aluno). Por fim, apelar a uma lealdade superior significa o sacrifício das normas dominantes em favor de deveres maiores com o seu grupo (tais como amigos, familiares, enfim, pessoas do seu meio).

Nesse diapasão, torna-se flagrante a coerência de tais técnicas com a já citada teoria do escudo ético. Pois, ainda que esta foque o apelo ao direito de vingança, preponderantemente, como escusa moral perante a opinião pública, não se pode negar, também, que ela aponta a necessidade psicológica do cangaceiro em adotar esse álibi como justificativa interna - uma forma de aliviar suas tensões e contradições individuais, decorrentes da incoerência entre os valores que segue e o seu agir.

Construído sob imperativo da consciência moral, o escudo ético destinava-se a preservar ambas as imagens, estabelecendo uma causalidade ética que, sendo embora simples produto de elaboração mental, lograva o efeito por assim dizer mágico de convencer a seu próprio construtor, aplacando-lhe os reproches da consciência, além de lhe fornecer excelente justificativa no plano social. ${ }^{29}$

A justificativa da vingança, por essa razão, cumpria uma dupla função: angariava o apoio do campesinato - e, assim, garantia a logística e os refúgios indispensáveis para a atuação do bando, através da ajuda dos denominados "coiteiros" - e criava um ideal para a carreira subversiva, uma razão superior, a fim de apetecer o remorso pelo descumprimento dos valores comunitários que ele abraçava.

Analisando-se profundamente, ver-se-á que cada técnica de neutralização delineada ajusta-se às escusas constantemente apresentadas pelos cangaceiros. Negando sua responsabilidade, Virgulino dizia "Eu hoje me queixo de estar nessa vida, agradeço àquele peste (José Saturnino) e ao tenente Lucena", como se, não fosse por eles perturbarem o cur-

${ }^{29}$ MELLO, Frederico Pernambucano de. Guerreiros do Sol: Violência e banditismo no Nordeste do Brasil. São Paulo: A Girafa, 2004. p. 133. 
so de sua vida, teria ele rejeitado o cangaço. Os "macacos" ${ }^{30}$, por sua vez, não eram vistos como vítimas. O "imposto" cobrado por Lampião, na sua concepção, não faria falta aos latifundiários - refutando, assim, seu caráter ilícito. O Poder Público que o condena é o mesmo que faz vista grossa às injustiças praticadas contra o pobre do campo - condenam-se, desse modo, os condenadores.

Por fim, apelava ao dever de "lavar" a honra de sua família contra as injustiças que lhe fizeram - primeiro, um latifundiário, José Saturnino, expulsando-os de suas terras, segundo, um policial, tenente Lucena, tirando a vida do seu pai -, como imperiosa obediência a uma lealdade superior. Sua carreira criminosa era um legítimo direito que detinha, segundo seu dever ético para com os seus semelhantes, capaz de excepcionar o ordenamento jurídico.

Há, portanto, certo exagero em denominar os cangaceiros como "coronéis sem terra" 31 , igualando a vítima de uma macroestrutura aos responsáveis pela sua opressão. É certo que eles não contribuíram para combater adequadamente o sistema que oprimia seus semelhantes, bem como exprimiram uma violência abjeta e descomunal, contudo, isso não se deu por um frio abandono dos seus valores comunitários, e sim pela impossibilidade de satisfazer, simultaneamente, os seus imperativos pessoais e as expectativas sociais que os circundavam.

Nesse sentido, Sykes e Matza definem bem - parecendo antever o que a criminologia crítica denunciaria anos depois - como o sistema penal, às vezes, define como crime o que para parcela da sociedade seria justificável (como, atualmente, tem ocorrido com a criminalização do aborto ou do uso de drogas):

... que gran parte de los delitos se basan en lo que constituye esencialmente una prolongación de los atenuantes de culpabilidad que se manifiestan como justificaciones de la desviación que son válidas para

\footnotetext{
${ }^{30}$ Denominação dada às volantes pelos cangaceiros.

${ }^{31}$ HOBSBAWM, Eric J. Bandidos. 4. ed. São Paulo: Paz e Terra, 2010. p. 385.
} 
los delincuentes, pero no para el sistema legal ni para la sociedad en su conjunto. ${ }^{32}$

É, no mínimo, utópico, esperar uma reação coerente e pacífica de indivíduos habituados à barbárie, sem qualquer acesso à educação em sua esmagadora maioria, analfabetos -, explorados física e moralmente até o seu limite e que, em contrapartida, são pressionados por um código moral extremamente rigoroso ${ }^{33}$. Como salientava Merton, a sociedade impõe metas e realizações que, por vezes, não são acompanhadas de meios legítimos e adequados para alcançá-las. Esse estado de anomia era a regra no sertão. Em virtude disso, acreditar que era factível a chance de o sertanejo, obedecendo aos valores dominantes, alcançar suas metas socioculturais, sem sentir-se atraído por uma via menos árdua, é mera ilusão. ${ }^{34}$

$\mathrm{O}$ auto-engano adotado pelos cangaceiros era uma reação a um cenário injusto, no qual seguir as normas gerais era distanciar-se das metas sociais ${ }^{35}$. Para alcançá-las, portanto, sem rejeitar os valores dominantes, era preciso artifícios engenhosos, tanto para aplacar as cobranças externas como internas. E no palco sertanejo, por sorte, havia uma excludente de culpabilidade que aparentava transitar pelas cinco técnicas de neutralização, qual seja, a vingança. ${ }^{36}$

${ }^{32}$ SYKES, Gresham M'Cready; MATZA, David. Técnicas de Neutralización: una teoría de la delincuencia. Salvador: Caderno CRH, 2008. Disponível em: <http://www.sc ielo.br/scielo.php?script=sci_arttext\&pid=S0103-49792008000100012>. Acesso em: 21 de agosto de 2014. p. 4.

${ }^{33}$ Aquelas reações populares que chegaram mais perto, como Canudos, Caldeirão e Paude-Colher, foram massacradas rapidamente, não durando nem metade da atuação do rei do Cangaço.

${ }^{34}$ MERTON, Robert K. Social Teoria y estrutura sociales; trad. Florentino M. Torner. México: Fondo de Cultura, 1964. p. 125.

35 "Puede sostenerse a priori que estas justificaciones de la desviación serán comprendidas con mayor facilidad por los segmentos de la sociedad a quienes les resulta evidente la diferencia entre los ideales sociales comunes y las prácticas sociales". (SYKES, Gresham M'Cready; MATZA, David. Técnicas de Neutralización: una teoría de la delincuencia. Salvador: Caderno CRH, 2008, p. 06. Disponível em: http://www.scielo.br/scielo.ph p?script=sci_arttext\&pid=S0103-49792008000100012. Acesso em: 21 de agosto de 2014).

${ }^{36}$ GIANETTI, Eduardo. Auto-engano. São Paulo: Companhia das letras, 1997. p. 291. 


\section{CONSIDERAÇÕES FINAIS}

Não se esperava, com este trabalho, uma resposta conclusiva acerca da natureza dos cangaceiros - se se tratavam de mocinhos ou vilões - e sim o alargamento da famosa linha tênue que se interpõe na clássica divisão entre o bem e o mal. Nessa busca, o artigo abriu muitas brechas para a atuação de outras teorias criminológicas - como deixa entrever a inserção providencial de autores como Zaffaroni, Merton e Alessandro Baratta - confirmando, assim, a inafastabilidade da interdisciplinaridade da criminologia, bem como que o seu atual estágio não comporta mais perspectivas simplificadoras e discriminatórias, tal como apregoavam as teorias etiológicas.

Imergindo em teorias diametralmente opostas, logrou-se estudar o cangaço nas suas características extremas, o que tinha de melhor e pior foi atentamente observado, por meio das teorias do banditismo social e do escudo ético. A primeira forneceu uma perspectiva dialética do fenômeno, encontrando, na análise do cenário político e econômico do sertão, o caráter dos seus representantes, descritos, assim, como vingadores sociais da classe camponesa, envoltos numa revolução primitiva e inconsciente contra a estrutura que os controlava. A teoria do escudo ético, por sua vez, aplaca o romantismo da anterior, referindo-se a tal protótipo de revolucionário como mais um a atuar em detrimento dos valores sociais dominantes, escondendo-se através do véu da vingança para aplacar a reprovação própria e alheia.

Apoiando-se na teoria das técnicas de neutralização, de Sykes e Matza, o tema logrou maior coerência. Sem negar a violência e barbaridade das condutas dos bandoleiros, tal perspectiva enquadrou tais comportamentos como uma reação inerente a um contexto social anômico. Ainda que reprovável segundo os padrões legais, não significava uma luta aberta contra a sociedade e todos seus valores. Ao revés, partia do confronto entre tais normas e as exigências superiores arraigadas às causas pessoais dos bandoleiros. A vingança não era, portanto, um artifício ardil para negar sua culpa, era, ao contrário, uma sincera necessidade psicológica de conformar valores distintos, porém, igualmente aceitos pelo seu autor.

Por se tratar de um trabalho pioneiro na seara criminológica, muitas perspectivas ainda cabem sobre o tema, sobretudo no âmbito da criminologia radical, haja vista sua confluência com as perspectivas marxistas do cangaço. 


\section{REFERÊNCIAS BIBLIOGRÁFICAS}

BARATTA, Alessandro. Criminologia crítica e crítica do direito penal: Introdução à sociologia do direito penal. 6. Ed. Rio de Janeiro: Revan, 2011.

CARVALHO, Salo de. Antimanual de Criminologia. 5. Ed. São Paulo: Saraiva, 2013.

CASTRO, Lola Aniyar de. Criminologia da libertação. Rio de Janeiro: Revan, 2005.

FACÓ, Rui. Cangaceiros e fanáticos: gênese e lutas. Rio de Janeiro: UFRJ, 2009.

GIANETTI, Eduardo. Auto-engano. São Paulo: Companhia das letras, 1997.

GOMES, Luiz Flávio; MOLINA, Antônio Gracia-Pablos de. Criminologia. 8. ed. São Paulo: Revista dos Tribunais, 2012.

HOBSBAWM, Eric J. Bandidos. 4. ed. São Paulo: Paz e Terra, 2010.

MARX, Karl. O capital: crítica da economia política. Livro I: o processo de produção do capital. São Paulo: Nova cultural, 1996.

MELLO, Frederico Pernambucano de. Guerreiros do Sol: Violência e banditismo no Nordeste do Brasil. São Paulo: A Girafa, 2004.

MERTON, Robert K. Social Teoria y estrutura sociales; trad. Florentino M. Torner. México: Fondo de Cultura, 1964.

PERICÁS, Luiz Bernardo. Os cangaceiros: Ensaio de interpretação histórica. São Paulo: Boitempo Editorial, 2010.

SYKES, Gresham M'Cready; MATZA, David. Técnicas de Neutralización: una teoría de la delincuencia. Salvador: Caderno CRH, 2008. Disponível em: $<$ http://www.scielo.br/scielo.php?script=sci_arttext\&pid=S01 03-49792008000100012>. Acesso em: 21 de agosto de 2014.

VAINSENCHER, Semira Adler. Cangaço. Pesquisa Escolar Online, Fundação Joaquim Nabuco, Recife. Disponível em: $<$ http://basilio.fundaj.gov.br/pesquisaescolar/>. Acesso em: 20 de agosto de 2014.

ZAFFARONI, Eugenio Raúl. A palavra dos mortos: conferências de criminologia cautelar. São Paulo: Saraiva, 2012.

. O inimigo no direito penal. 2. Ed. Rio de Janeiro: Revan, 2007. 
